U.S. Department of Agriculture

Animal \& Plant Health Inspection Service Wildlife Services

January 2018

Wildlife Damage Management Technical Series

\title{
Wild Turkeys
}

James E. Miller

Professor Emeritus

Mississippi State University

Starkville, Mississippi

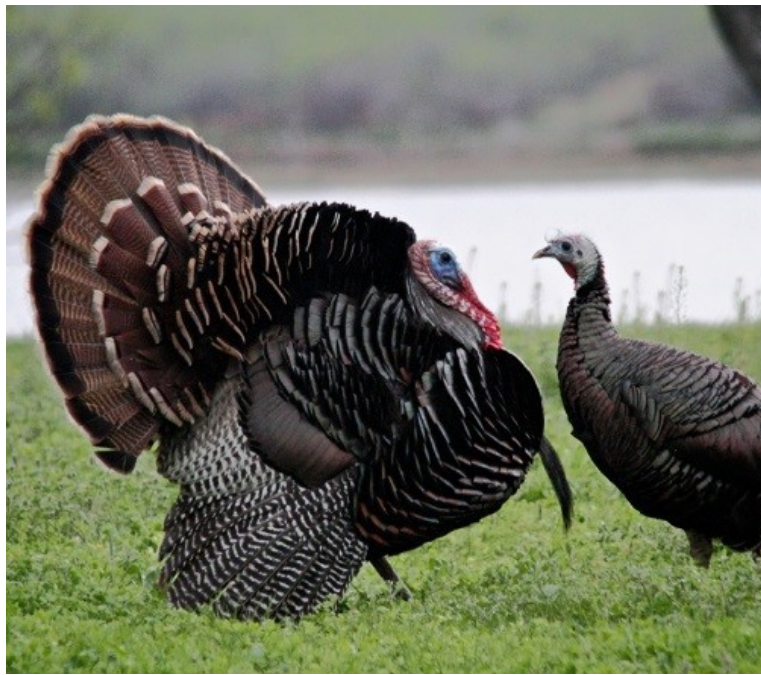

Figure 1. Male (left) and female (right) wild turkeys (Meleagris gallopavo)

\section{Human-Wildlife Conflicts}

Like other bird and mammal species whose populations have been restored through conservation efforts, wild turkeys (Figure 1) are treasured by many recreationists and outdoor enthusiasts. Wild turkeys have responded positively to wildlife habitat and population management. In some areas, however, their increased populations have led to increased damage to property and agricultural crops, and threats to human health and safety.

Turkeys frequent agricultural fields, pastures, vineyards and orchards, as well as some urban and suburban neighborhoods. Because of this, they may cause damage or mistakenly be blamed for damage. Research has found that despite increases in turkey numbers and complaints, damage is often caused by other mammalian or bird species, not turkeys. In the instances where turkeys did cause damage, it was to specialty crops, vineyards, orchards, hay bales or silage pits during the winter. In cultured crops or gardens where wood chips, pine straw or other bedding materials (mulch) are placed around plants, wild turkeys sometimes scratch or dig up the material and damage plants when searching for food.

Wild turkeys can also be aggressive towards people, especially during the breeding season. 


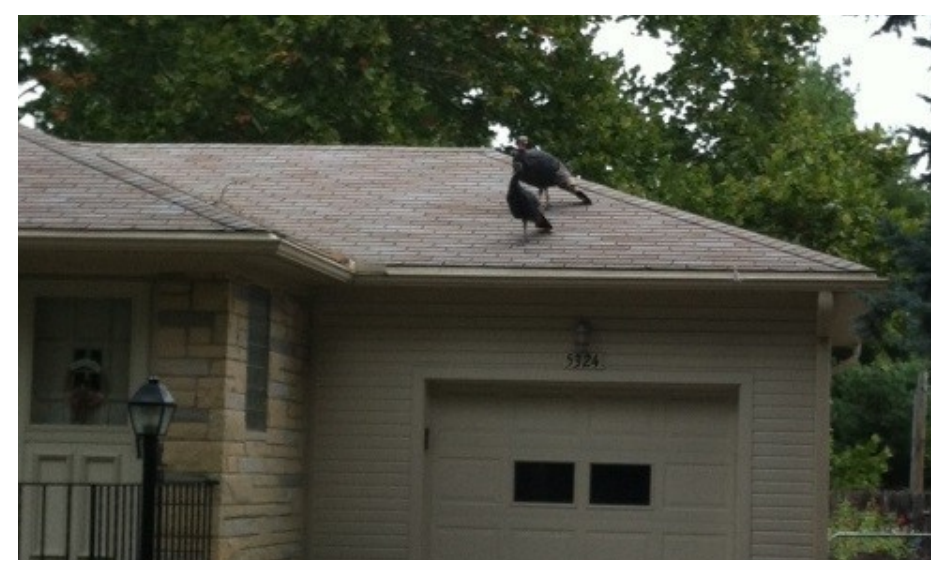

Figure 2. Turkeys on a roof in a residential neighborhood.

\section{Crops}

Reports of wild turkey damage to agriculture have increased as turkey populations have expanded. Reports often come during the growing season when turkeys are seen in corn, soybean, sorghum, peanut, melon, bean and pea fields, and other small grain and vegetable crops. Turkeys may cause damage to fruit orchards, grape vineyards, and specialty crops that are mulched or bedded. Wild turkey damage also occurs in open silage pits and from scratching wheat, oat or hay bales during the winter.

Studies done within the last 15 years show the majority of damage, particularly in agricultural crops, attributed to wild turkeys is actually caused by other wildlife species. Wild turkeys observed in crop fields, orchards or vineyards during the growing season are likely feeding on other foods, such as insects, weeds or waste grain/seeds from previous crops. A wildlife damage management professional should assess the situation before management action is taken.

\section{Human Health and Safety}

Wild turkeys that adapt to urban or suburban communities, especially young and mature males during the breeding season, can become quite aggressive towards people. Rarely do they cause serious damage, although they often will chase and harass children. Elderly individuals are also at risk from falls associated with aggressive turkeys.
Wild turkeys, like other wildlife species, can become a hazard to people and rarely survive collisions with airplanes and cars. According to the Federal Aviation Administration's Wildlife Strike Database, a total of 61 collisions occurred between wild turkeys and airplanes across 24 states from 2000-2017.

Wild turkeys are susceptible to a number of diseases, as well as both internal and external parasites. Some common infectious diseases include avian pox, Lymphoproliferative neoplasms (transmissible tumors), infectious sinusitis and histomoniasis (blackhead disease). Most of these are transmitted to wild turkeys from domestic poultry sources. Although these and other infectious diseases are sometimes found in wild turkeys, none are known to pose a human health threat. However, health experts recommend not handling nor eating wild turkeys known to have an infectious disease.

Wild turkeys are also hosts for a variety of internal parasites, including protozoans, trematodes, cestodes, acanthicephalans, nematodes and arthropods. Except for the protozoa Histomonas meleagridis, these parasites rarely cause mortality in wild turkeys. Although weakened birds are more susceptible to predators and disease. External parasites found on turkeys include ticks, mites, lice and louse flies. Some of these can be transmitted to people. Wear appropriate protective gear, such as rubber gloves, when handling live or harvested turkeys.

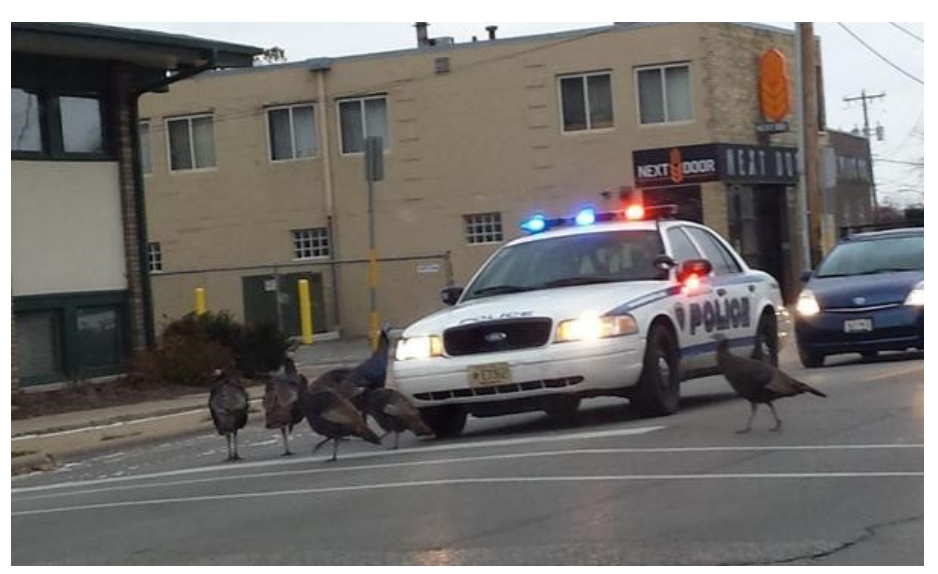

Figure 3. Wild turkeys blocking traffic. 


\section{Structures}

Like other territorial birds, wild turkeys often perceive their reflection as an intruding bird and attack the reflective surface. For instance, a wild turkey may scratch or damage a window, door or mirror on a parked vehicle when it sees its reflection. Turkeys may also repeatedly attack ground level windows on residential and commercial buildings. The behavior can go on for days or weeks, possibly damaging the window or the trim surrounding the window.

\section{Nuisance}

Nuisance reports of wild turkeys in rural, suburban and urban areas include scratching in yards, flower beds, mulched areas or gardens; using bird feeders; leaving fecal droppings on yards, decks, porches, and sidewalks; attacking reflections in glass or sides of vehicles; damage to roofing materials from roosting (Figure 2); noise from roosting birds; fecal and scratch damage left on parked cars or trucks; aggressive behavior towards people; and impeding traffic (Figure 3). Much of this is caused by habituation to people.

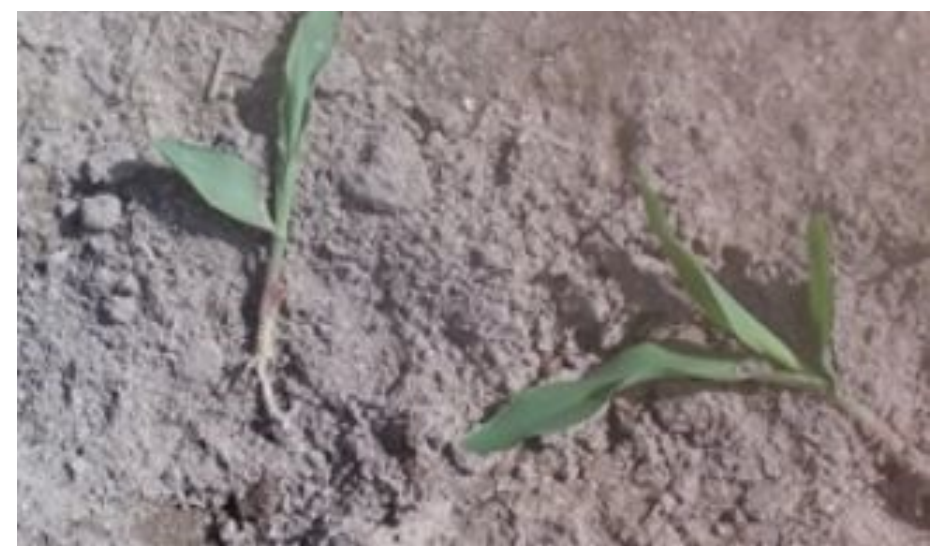

Figure 4. Wild turkey damage to corn seedlings.

\section{Damage Identification}

Wild turkey damage can often be difficult to distinguish from other wildlife damage. It includes feeding on seeds, seedlings or other plant material (Figure 4); scratching and digging up mulch and other gardening materials; damaging cars, windows or other reflective surfaces; and polluting areas with fecal material.

\section{Management Methods}

No single management method to prevent wild turkey damage works all the time or in all settings. Generally, management methods should be combined so that one method enhances the effects of another.

Because of existing regulations on the harassment or lethal removal of wild turkeys, contact a state or federal agency natural resources professional to assess the situation, confirm it is wild turkey damage, and provide damage management recommendations.

\section{Habitat Modification}

The best way to modify the habitat to prevent wild turkey damage is to eliminate access or remove attractants, such as bird feeders, livestock feed or other food sources.

Covering mulched areas or fencing small flower gardens, vegetable gardens or vineyards when feasible may also help reduce damage. Landowners may also control insect populations to reduce the availability of this food source.

\section{Exclusion}

Excluding wild turkeys from areas is difficult as they can fly and will often fly over low fences. Fencing can deter, but not prevent, wild turkey access to highly attractive areas. The cost of excluding wild turkeys may be worthwhile to prevent damage to specialty crops or smaller flower and vegetable gardens. 


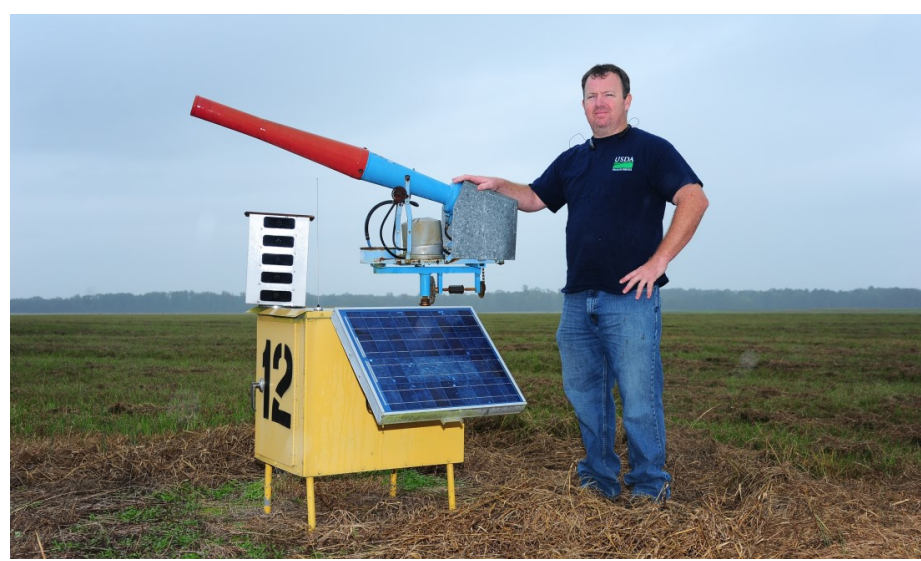

Figure 5. Propane cannons are noise devices used to scare birds and other wildlife.

\section{Fertility Control}

None available.

\section{Frightening Devices}

Multiple nonlethal frightening devices or harassment methods are available for use with wild turkeys. They are only effective for short periods of time as birds quickly become habituated to them. For best results, use a variety of devices and change their location and frequency of use regularly.

\section{Auditory and Visual}

Although wild turkeys vocalize distress and alarm calls, using the recordings of such calls as frightening devices only deters wild turkeys for a short period of time.

Some frightening devices, such as Mylar ${ }^{\circledR}$ tape and balloons tied or attached to stakes, owl effigies/decoys, and scarecrows are used with limited success. Motionactivated sprinklers can be used to keep wild turkeys out of flowerbeds. Inflatable air dancers have been used to scare turkeys from roost trees.

When applied at varying locations and intervals, pyrotechnics can effectively scare both individual wild turkeys and flocks. These wildlife control explosives include a variety of different products, such as shell crackers, 15-mm pyrotechnics (e.g., screamers and bangers), and long range pyrotechnics (e.g., CAPA rounds). Users should be trained in the safe use and handling of these tools to prevent injury and fires. Permits from the Bureau of Alcohol, Tobacco and Firearms are required for the use of some classes of pyrotechnics by individuals and nongovernmental entities.

Propane cannons are noise-making devices (Figure 5). These devices can be placed at locations and activated by a timer or remote control. Birds quickly habituate to propane cannons, if their use is predictable. Move the device frequently and only trigger it when necessary.

\section{Biological}

Harassment using human or other animal activity (such as a pet dog) in an area frequented by wild turkeys can be an effective deterrent. Check local and state regulations before attempting as this may not be legal in some areas.

Where legal, exhibit dominant behavior toward turkeys, scare them with loud noises and chase them off the property. Defend against aggressive turkeys with a broom, open umbrella, cane or spray them with a water hose.

\section{Repellents}

No repellents are currently registered for use with wild turkeys.

\section{Shooting}

Most states have official hunting seasons for wild turkeys which can help alleviate damage associated with the birds. If the level of complaints is high, the respective state or provincial fish and wildlife agency may expand hunting seasons (e.g., lengthen a season or increase the bag limit) in the specific management zone or area where damage has been confirmed. However, most often they will be reluctant to change seasons or bag limits, and may instead provide damage permits to the individuals or communities where significant damage is occurring. In situations where wild turkeys threaten public safety (i.e., birds at airports), state or federal agencies often remove individuals or flocks through trapping or lethal control. 


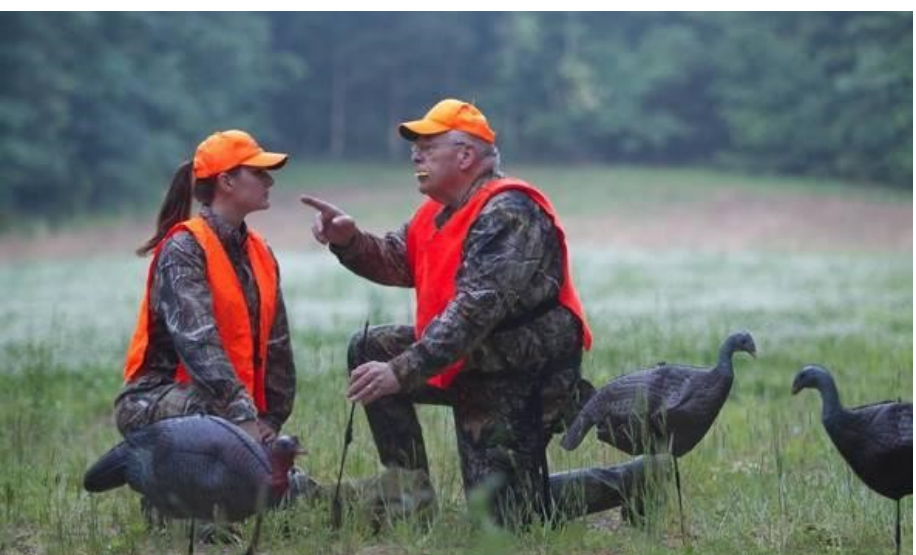

Figure 6. Wild turkeys are hunted throughout the continental United States.

\section{Toxicants}

No toxicants are currently registered for use with wild turkeys.

\section{Trapping}

Wild turkeys can be live-trapped using several trapping tools and techniques, including rocket or cannon nets over baited sites, large drop net traps over baited sites, and net guns over baited sites.

In some situations, wild turkeys may be captured and moved by USDA Wildlife Services or state officials particularly if the state is trying to establish flocks in currently unoccupied, but suitable, habitats.

\section{Euthanasia}

Shooting is the most common method of humane killing for wild turkeys. Cervical dislocation and carbon dioxide gas are also used.

\section{Disposal}

Check local and state regulations regarding carcass disposal.

\section{Economics}

Wild turkeys are treasured game birds that are avidly sought after by recreational users, including hunters and other wildlife enthusiasts (Figure 6). The economic value for spring gobbler season to the local, state, and U.S. economy was estimated at $\$ 4.4$ billion according to a study by Southwick Associates. The 2003 study estimated that nationally, more than 2.2 million spring gobbler hunters spent nearly $\$ 1.8$ billion and stimulated a total economic activity of $\$ 4.4$ billion. This supported 41,323 jobs, $\$ 88.9$ million in state sales tax and income tax revenues, and $\$ 198.6$ million in federal income tax.

The extent of damage and economic losses from wild turkeys is unknown. One appraisal estimated wild turkey damage to agricultural crops in Wisconsin from 20052016 to be $\$ 654,970$ with the majority associated with ginseng (Figure 7). This multi-year crop is grown under shade and covered with straw for winter protection. Wild turkeys frequent the shaded areas in search of insects and seeds in the winter. Their scratching damages the plants.

Fortunately, where turkeys cause damage, a variety of acceptable prevention or control techniques can be implemented. Anyone with concern about wild turkey damage or threats to public safety should contact their state or federal wildlife agency for assistance.

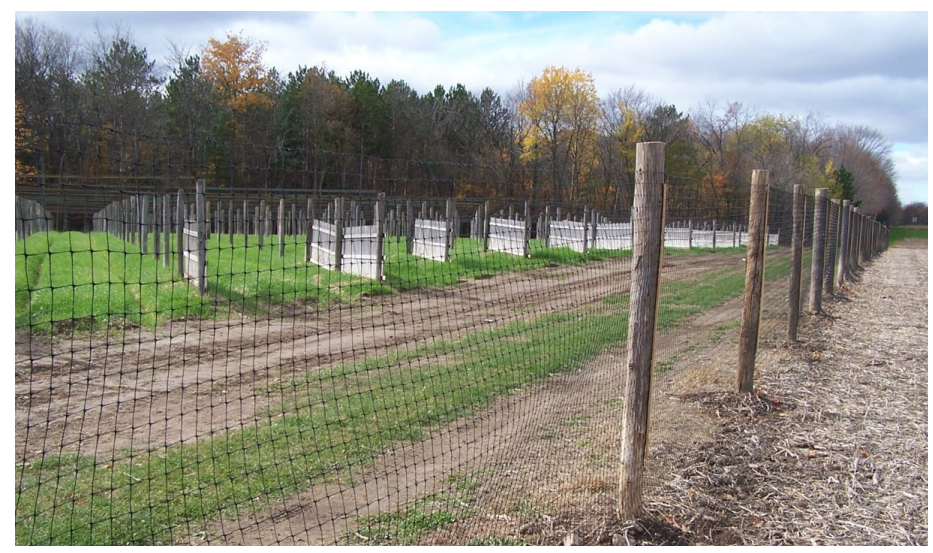

Figure 7. Ginseng is a valuable specialty crop that has experienced damage from wild turkeys. 


\section{Species Overview}

\section{Identification}

The term "wild turkey" refers to members of five North American subspecies that belong to the order Galliformes, family Meleagridae, and genus Meleagris. Currently, wild turkeys are in the subfamily Meleagridinae within the family Phasianidae. Subspecies commonly recognized in North America include:

- $\quad$ Eastern wild turkey (Meleagris gallopavo silvestris);

- $\quad$ Florida wild turkey (M. gallopvo osceola);

- $\quad$ Rio Grande wild turkey (M. gallopavo intermedia);

- $\quad$ Merriam's wild turkey (M. gallopavo merriami); and

- $\quad$ Goulds wild turkey (M. gallopavo Mexicana).

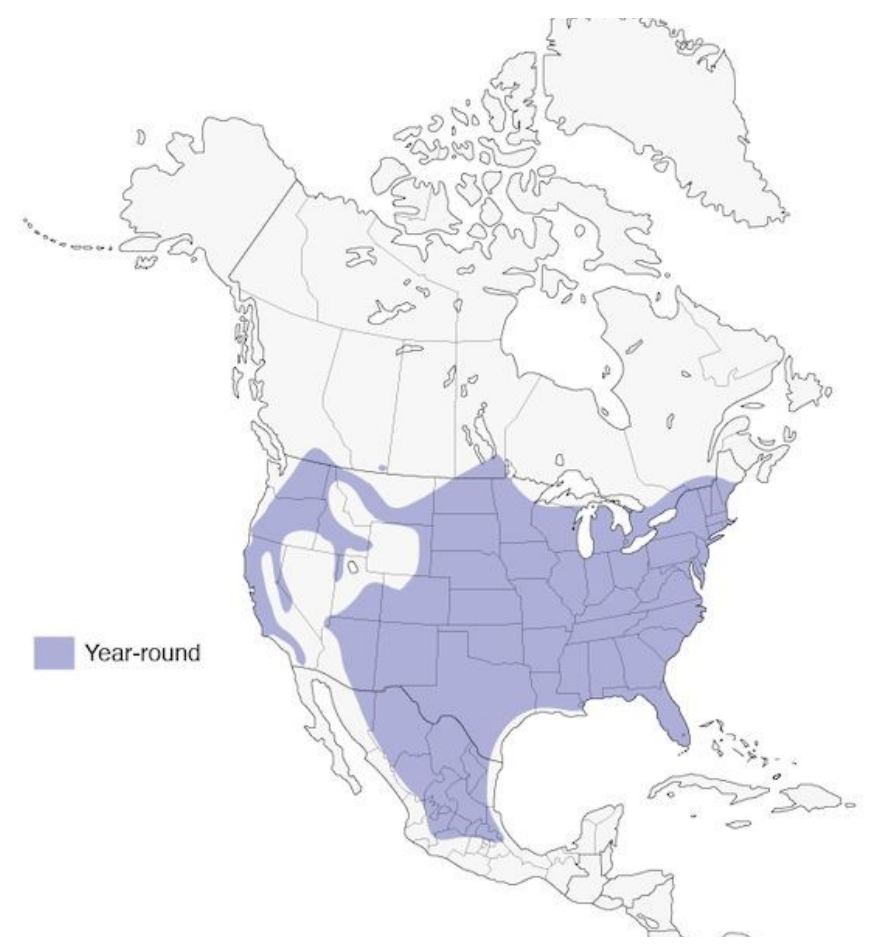

Figure 8. Range of wild turkey.

\section{Physical Description}

Wild turkeys are large, sexually-dimorphic birds with long legs, wide and rounded tails, long necks and small heads. Large adult males (also known as toms or gobblers) may weigh from 15 to 35 pounds throughout their range in North America, with the average being 17 to 21 pounds. Females (or hens) usually do not exceed 13 pounds, with the average size 8 to 11 pounds.

Large feet and powerful legs enable the turkey to run between 12 to 18 miles per hour. They also enable the birds to scratch through leaves, duff, and heavy soil, and burst into flight.

Wild turkeys have dark, bronze-green iridescent feathers over most of their bodies. The "beard" that grows from the center of the turkey's breast is made from feathers that look like hair. They are commonly found on adult males and occasionally on females. Depending upon their physiological state during the breeding season, the bare skin on the males' heads and necks can change quickly from a bluish-gray color to brilliant red, white and blue that is very noticeable to female turkeys and hunters.

Each subspecies is distinguished primarily by different colored tail feather tips, rump patches or wing feather barring, as well as other distinguishing features (e.g., length of leg bone). Where two or more subspecies' ranges overlap, interbreeding can occur making it difficult to recognize distinct subspecies.

\section{Range}

Significant restoration efforts by state and federal wildlife agencies during the last half of the $20^{\text {th }}$ century have enabled wild turkey populations to become established and sustained in 49 of the 50 states (including Hawaii) within the U.S. and six provinces in Canada (Figure 8). Some populations have also been established in New Zealand and several European countries.

\section{Voice and Sounds}

Wild turkeys have many distinct vocalizations. Recreational hunters try to imitate the "yelp" and other calls of female 
turkeys to attract males to their location, and sometimes a gobble call is used as well to challenge aggressive males. Both male and female wild turkeys will cluck and purr when content.

Turkeys have acute hearing even though they do not possess visible external ears. The ear opening is covered with fine bristle feathers. They do not have ear flaps or pinnae which normally concentrate sound waves. Research indicates that turkeys hear lower pitched and more distant sounds than people, and can readily distinguish the location of calls from other turkeys or people imitating turkey calls.

\section{Tracks and Signs}

Wild turkeys often leave tracks and other signs, such as feathers, droppings and dusting areas. Wild turkey tracks show three toes forward and one smaller toe backward, and measure about $33 / 4$ to 5 inches long by 4 to $5 \frac{1}{2} 2$ inches wide (Figure 9), with male turkey tracks considerably larger than female tracks.

Wild turkey droppings of adult hens are usually looped, spiral or bulbous in shape, whereas adult gobbler droppings are usually in a J or L shape, straighter, longer and larger in diameter. Both may have portions of the dropping that are lighter in color. Dusting areas are shallow depressions in dry dirt or sandy ground where the birds take dust baths. Feathers and scratch marks may be present.

\section{Reproduction}

Wild turkeys are polygynous (i.e., males mate with many females). Their breeding behavior is triggered primarily by the increase of daylight hours in the spring, although unseasonably warm or cold weather may advance or delay breeding activity. Male wild turkeys have an elaborate courtship behavior called "strutting" that begins during late winter. They puff out their feathers, spread their tails and drag their wings. Males can breed and inseminate females throughout the spring and early summer months.

Turkeys are ground nesters. Females typically lay between 4 and 17 eggs. Incubation is between 25 and 31 days.

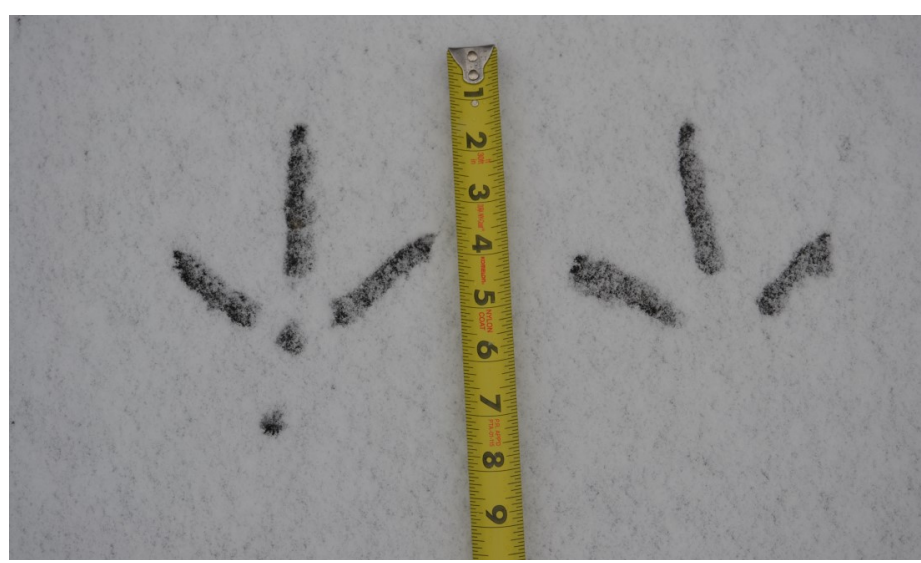

Figure 9. Wild turkey tracks. Note right track is missing the imprint of the back toe.

Females will nest again, if their nests are predated or destroyed. However, subsequent nests are usually less productive. Young turkeys (poults) are precocial, staying with the adult female through the fall (males) and early spring (females).

\section{Mortality}

The mean life expectancy of wild turkeys is 1.3 to 1.6 years, although one banded wild turkey lived up to 10 years.

Adult females, eggs, and poults up to a few weeks old are extremely vulnerable to predators. In addition to predation and human hunting, other causes of mortality include weather (i.e., rain and cold temperatures), diseases and body parasites.

\section{Population Status}

In the early 1900s, fewer than 40,000 wild turkeys existed throughout North America. In 1959, wild turkey populations within the U.S. were estimated at 250,000 birds. Today, as a result of successful restoration efforts and their adaptability, wild turkeys are commonly observed throughout most of North America. Their population is estimated between 6.5 to 6.7 million birds. 
Habitat

Wild turkey habitat includes riparian zones, oak forests, pine savannas, forest clearings, grasslands, meadows and pastures. Forested areas are often used for foraging, daytime resting and escape cover, and nighttime roosting. Grasslands and other open areas are used primarily for foraging (Figure 10).

Although originally thought to be limited to large remote forested areas, wild turkeys have adapted to a variety of habitats including some urban and suburban areas. Human-impacted landscapes are often where most conflicts occur between people and wild turkeys.

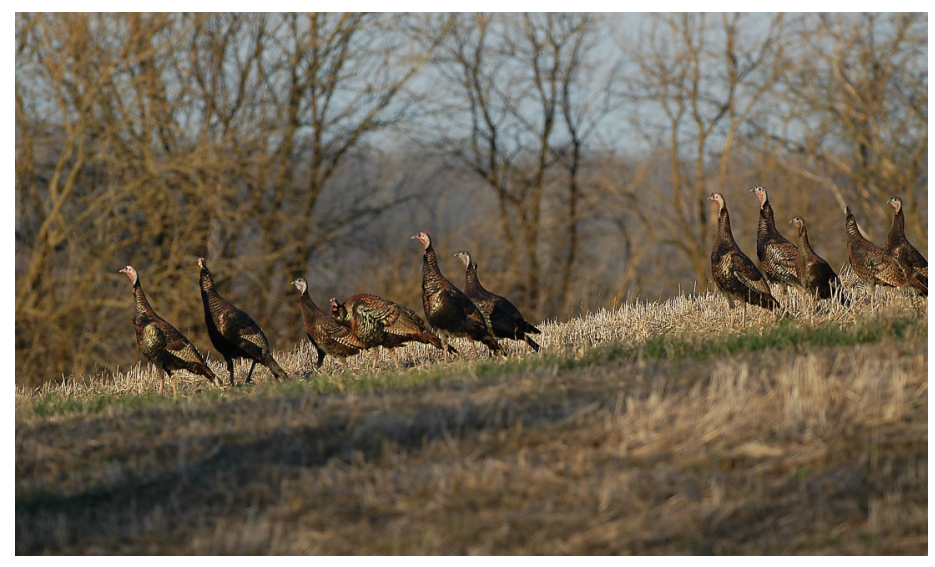

Figure 10. Wild turkey habitat is a mixture of forested areas and meadows.

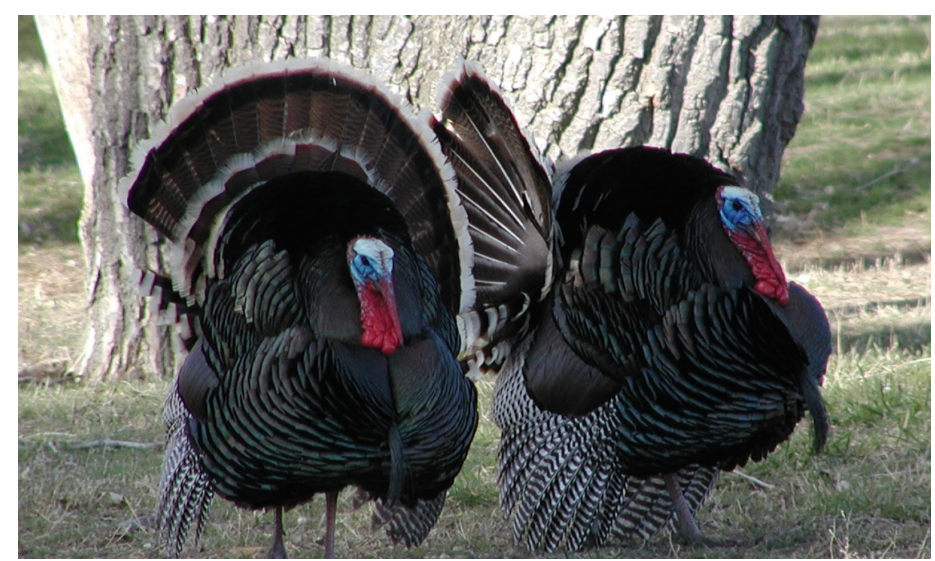

Figure 11. Strutting wild turkeys.

\section{Behavior}

Wild turkeys are highly social animals usually forming large flocks. For instance, female brood flocks may contain 200 or more individuals during the winter when many broods gather together.

Male turkeys compete for females. Courting males gobble and display to attract females and warn competing males (Figure 11). Fighting between males is common during the breeding season.

Wild turkeys have excellent vision. Like many other birds, they can detect color and variations of color. Because their eyes are on the side of their head, turkeys have predominantly monocular, periscopic vision. By turning their head slightly, turkeys have a $360^{\circ}$ field of vision. Their night vision is poor and the birds are primarily active during the daylight hours.

Although they mostly get around by walking, wild turkeys can fly. If startled, they may take to the air or run. Flying close to the ground, they can travel up to a quarter mile (400 meters) at a time. A wild turkey in flight has been clocked at up to 55 miles per hour.

\section{Food Habits}

Wild turkeys have a poor sense of taste and smell because they have few taste buds and very small olfactory lobes in the forepart of the brain. In food selection, color and shape appear to be much more important than either taste or smell.

Wild turkeys are omnivorous ground feeders, that forage opportunistically on both plants and animals, including nuts, seeds, fruits, insects, and small reptiles. The shape of their bill enables them to peck through forest litter and eat fairly large items, such as acorns and hickory nuts (0.5 to 2.5 inches).

Examinations of wild turkey crops and gizzards reveal that 354 species of plants and some 313 species of animal matter have been eaten by wild turkeys. Feeding activity by wild turkeys is best described as opportunistic and 
nomadic, in that they seem to wander aimlessly, yet are very purposeful in locating and obtaining various food items. Their scratching and pecking behavior aids in finding and obtaining different foods. They will scratch in flowerbeds or garden sites when available. Like most animals, turkeys will feed on food from waste grain, bird feeders and deer baiting sites.

Turkeys typically feed soon after leaving their roosts early in the morning, and again in the mid- to late afternoon before heading back to their roosts.

\section{Legal Status}

Wild turkeys are a valuable game species, treasured by recreational hunters and wildlife enthusiasts. State, federal, and provincial wildlife management agencies, as well as private landowners across the nation, take great pride in the fact that wild turkey populations have been restored and managed for many years with great success.

Agencies carefully regulate the taking of wild turkeys. A resident or non-resident license and, in some states, appropriate stamps or permits are required to legally harvest wild turkeys. Most states have spring and fall turkey seasons, although season schedules, bag limits, and related restrictions may vary by state. Additionally, regulations regarding the harassment, management or taking of wild turkeys because of damage or human health and safety threats also vary by state. Check requirements in your state or province before initiating any management practices. 


\section{Acknowledgements}

Figure 1. Photo by Robert Burton, USFWS

Figure 2. Photo by Stephen Vantassel

Figure 3. Photo by Madison Wisconsin Police Department

Figure 4. Photo by Bill Cissel, University of Delware Cooperative Extension

Figure 5. Photo by Daniel Lile, Department of Defense U.S. Air Force

Figure 6. Photo by Missouri Department of Conservation

Figure 7. Photo by Jim Tharman, USDA Wildlife Services

Figure 8. Map by The Birds of North America Online (A. Poole, Ed.). Ithaca: Cornell Lab of Ornithology

Figure 9. Photo by Wikimedia Commons, Virginia State Parks

Figure 10. Photo by Ohio Department of Natural Resources

Figure 11. Photo by Kevin Keirn

\section{Glossary}

Brood: A family of young birds.

Crop: A muscular pouch near the throat of a bird used to temporarlily store food.

Gizzard: A muscular part of a bird's stomach for grinding food, typically containing grit.

Gobbler: Male wild turkey.

Poult: A young turkey.

Precocial: Young that leave the nest immediately upon hatching or birth and require limited parental care.

Pyrotechnics: Flares or cartridges fired from a gun or launcher that produce a loud blast or scream accompanied by smoke and a flash of light.

Sexually dimorphic: The males and females of a species show differences in coloration, size or body structure.

\section{Key Words}

Game bird, Meleagris gallopavo, Wild turkey

\section{Disclaimer}

Wildlife can threaten the health and safety of you and others in the area. Use of damage prevention and control methods also may pose risks to humans, pets, livestock, other non-target animals, and the environment. Be aware of the risks and take steps to reduce or eliminate those risks.

Some methods mentioned in this document may not be legal, permitted, or appropriate in your area. Read and follow all pesticide label recommendations and local requirements. Check with personnel from your state wildlife agency and local officials to determine if methods are acceptable and allowed.

Mention of any products, trademarks, or brand names does not constitute endorsement, nor does omission constitute criticism.

\section{Citation}

Miller, J.E. 2018. Wild Turkeys. Wildlife Damage Management Technical Series. USDA, APHIS, WS National Wildlife Research Center. Fort Collins, Colorado. 12p. 


\section{Resources}

Davidson, W.R. and V.F. Nettles. 1997. Field manual of wildlife diseases in the Southeastern United States. Southeastern Cooperative Wildlife Disease Study. Univ. of Georgia, Athens, GA. pp. 263-284.

Davidson, W.R. and E.J. Wentworth. 1992. Population influences: diseases and parasites. Pages 101-118 in Dickson, J.G., editor. The wild turkey: biology and management. Stackpole Books. Harrisburg, Pennsylvania. USA.

Gregonis, M.A., B.J. Hiller, R.E.A. Eriksen, and B.C. Tefft. 2011. Assessment of wild turkey-human conflicts throughout the United States and Canada. Proceedings of the National Wild Turkey Symposium 10:31-39.

Groepper, S.R., S.E. Hyngstrom, B. Houck, S.M. Vantassel. 2016. Real and perceived damage by wild turkeys: a literature review. Proc. Nat. Wild Turkey Symp. Vol. 11, pp. 371-378.

Humberg, L.A., T.L. DeVault, B.J. McGowan, J.C. Beasley, and O.E. Rhodes, Jr. 2005. Crop depredation by wildlife in northcentral Indiana. Proceedings of the National Wild Turkey Symposium 9:59-65.

Hurst, G.A. 1992. Foods and feeding. Pages 66-83 in J.G. Dickson, editor, The Wild Turkey-Biology and Management. Stackpole, Harrisburg, Pennsylvania, USA.

Miller, J.E., B.C. Tefft, R.E. Eriksen, M. Gregonis. 2000. Turkey damage survey: a wildlife success story becoming another wildlife damage problem. Proceedings Ninth Wildlife Damage Management Conference. 9:24-32. State College, Pennsylvania, USA.

McRoberts, J.T., M.C. Wallace and S.W. Eaton. 2014. Wild Turkey (Meleagris gallopavo), version 2.0. In The Birds of North America (P. G. Rodewald, editor). Cornell Lab of Ornithology, Ithaca, New York, USA. https://doi.org/10.2173/bna.22

Mosby, H.S., and C.O. Handley. 1943. The wild turkey in Virginia: its status, life history, and management. Virginia Division of Game, Commission of Game and Inland Fisheries. P.R. Projects. 281 pp.

National Wild Turkey Federation Technical Committee 2012. White paper: Addressing problems associated with abundant wild turkeys. 5 pp. National Wild Turkey Federation. Edgefield, S.C., USA.

National Wild Turkey Federation Technical Committee. 2003. California vineyard study. White paper: identifying species responsible for wine grape depredations in California. 9 pp. A joint study by the California Department of Fish and Game and the National Wild Turkey Federation.

Pelham, P.H., and J.G. Dickson. 1992. Physical characteristics. Pages 32-45 in J.G. Dickson, editor, The Wild TurkeyBiology and Management. Stackpole, Harrisburg, Pennsylvania. USA.

Sanderson, G.C. and H.C. Shultz. 1973. Wild turkey management-current problems and programs. Univ. of Missouri Press. Columbia, MO. pp. 159-173.

Southwick Associates, Inc. 2003. The economic contributions of spring turkey hunting. Study prepared for National Wild Turkey Federation. Fernandina Beach, Florida. August, 2003. 17pp.

Teft, B.C., M.A. Gregonis, R.E. Ericksen. 2005. Assessment of crop depredation by wild turkeys in the United States and Ontario, Canada. Wildl. Soc. Bull. 33: 590-595. 


\section{Appendix}

Damage Management Methods for Wild Turkeys

\begin{tabular}{l|l}
\hline Type of Control & Available Management Options \\
\hline Exclusion & Install fencing or other barriers to prevent access
\end{tabular}

Exclusion Install fencing or other barriers to prevent access

Fertility Control None available

Frightening Devices - Pyrotechnics and propane cannons

- $\quad$ Mylar ${ }^{\circ}$ tape, scare-eyes, balloons, kites, and effigies.

- Dogs or human presence in an area

Habitat Modification - Eliminate attractants, such as bird feeders.

- Cover mulched areas

- Fence small gardens

Repellents None available

Shooting Allowed with proper State permits or hunting licenses

Toxicants None available

Trapping Allowed with proper State permits; Live-trapping with rocket or cannon nets, drop nets or net guns. 